\title{
Rosa's Theory of Resonance: Its Importance for (the Science of) Religion and Hope
}

\author{
Bojan Žalec
}

check for

updates

Citation: Žalec, Bojan. 2021. Rosa's Theory of Resonance: Its Importance for (the Science of) Religion and Hope. Religions 12: 797. https:// doi.org/10.3390/rel12100797

Academic Editors: Michal Valčo, Jove Jim S. Aguas and Kamil Kardis

Received: 7 September 2021

Accepted: 18 September 2021

Published: 24 September 2021

Publisher's Note: MDPI stays neutra with regard to jurisdictional claims in published maps and institutional affiliations.

Copyright: (C) 2021 by the author. Licensee MDPI, Basel, Switzerland. This article is an open access article distributed under the terms and conditions of the Creative Commons Attribution (CC BY) license (https:// creativecommons.org/licenses/by/ $4.0 /)$
Faculty of Theology, University of Ljubljana, 1000 Ljubljana, Slovenia; bojan.zalec@teof.uni-lj.si

\begin{abstract}
This article deals with the resonance theory of the German sociologist Hartmut Rosa, which has aroused a lot of interest among scholars in the humanities and social sciences, including researchers in the field of religion. The article focuses on its importance for religion, particularly the science of religion and hope. The author presents Rosa's theory first from the anthropological and sociological aspect. He then turns to Rosa's understanding of religion. On this basis, the author draws his conclusions, which are as follows: The main significance of the resonance theory for religion and the science of religion is in the rehabilitation of religion as an anthropological constant. It follows that Rosa's theory of resonance is an important contribution to substantiating the importance of religion and supporting its cultivation. Secondly, Rosa's theory is an important contribution and support to the flourishing of hope due to its scientific support for religion. Another contribution of Rosa's theory to hope is that it helps us understand the connection between resonance, existential hope, and meaning, and thus contributes to our being more successful in developing existential hope and discovering the meaning of our lives and world. This is important for our quality of life.
\end{abstract}

Keywords: Hartmut Rosa; theory of resonance; religion; science of religion; hope

\section{Introduction}

In this article, I deal with the resonance theory of the German sociologist Hartmut Rosa. This is, in Rosa's own words, a sociological theory of our relationship to the world as the subtitle of his major work on resonance (Rosa 2016, 2019c). The theory is very interdisciplinary and holistic. In it, philosophy, phenomenology, hermeneutics, social critique, and normative theory are intertwined with sociology (Hübner 2021, p. 225). We could also mention some other disciplines. Rosa's theory has aroused great interest among representatives of various disciplines of the humanities and social science, including representatives of the science of religion (Peters and Schulz 2017; Kläden and Schüßler 2017; Wils 2019; Rosa and Henning 2019; Laube 2018; Rosenstock 2018; Klun 2020; Hübner 2021; Žalec 2021). It is very important for the science of religion, as the religious relationship is at its core a resonant relationship (Klun 2020, p. 290). For this reason, the first main aspect from which I deal with it is its importance for religion and the science of religion (theology, philosophy of religion, religious studies, sociology of religion, etc.).

The second main topic I discuss in the context of Rosa's theory is hope. At the end of his book, Rosa writes that a better world is possible (Rosa 2019c, p. 459). This is without doubt a statement of hope. Jörg Hübner wrote that "the concept of resonance is a comprehensive systemic program of hope" (Hübner 2021, p. 225). The core of Rosa's understanding of the perspective of hope is the belief that a better world is only possible if we improve our relationships in all dimensions so that they become more resonant (Rosa 2017, pp. 41-46). Therefore, the key to a better world is resonance. In this article, I focus on the existential hope and religious aspect of Rosa's theory, as this aspect is the most important from the perspective of existential hope. Rosa defines religions as promises of resonance (Rosa 2019c, pp. 258, 265, 267). We can add that they are also important sources of existential hope. I explain this thesis in what follows. 


\section{Essential Features of Resonance}

Let us now briefly explain Rosa's notion of resonance (Rosa 2017, pp. 34-41). Rosa understands resonance as a relationship with the world in various dimensions. It is a twosided relationship or reciprocal relationship (Rosa 2019a, p. 27), which means that resonance requires both a receptive, pathic relationship, and, at the same time, an active relationship of both participants in resonance. It has four essential characteristics that apply to both sides in the resonance relationship (Rosa 2019b, p. 196): (1) affection (Ger. Affizierung); (2) self-efficacy (Ger. Selbstwirksamkeit); (3) transformation (Ger. Transformation); and (4) uncontrollability (Ger. Unverfügbarkeit (Rosa 2018, 2019d).

From what has been said, it is already clear that responsiveness is an integral part of resonance. The opposite of resonance is alienation, which is a "relationship" of indifference or even hostility. To the alienated subject, the object or world appears as dumb, deaf, unresponsive, as bare available material, and so on. It is a dead relationship, a relationless "relationship" (Rosa 2019c, p. 184). Buber's I-Thou relationship is resonance, and I-It relationship is alienation (Žalec 2021, p. 144). I am in resonance with someone if we are both touched, if I affect them and they affect me, and if this relationship-more or less-transforms us both. Resonance cannot be controlled; it is not accessible or available to us in the sense of Verfügbarkeit. In the relationship of resonance, the participants do not instrumentalize each other. An example of a resonant relationship is mutual love, and resonance is also an essential component for faith.

\section{Resonance Theory from the Anthropological and Sociological Point of View}

The opposite of alienation is, as already mentioned, resonance. However, the relationship between alienation and resonance is not a mere opposite, but a dialectical relationship (Rosa 2019c, p. 184ff), since resonance is possible only on the basis of a silent, alienated world (p. 190). Resonance is the opposite of alienation, but on the other hand, without alienation there is no resonance; moreover, resonance is not an alternative to alienation, but only a flash in an alienated world (Laube 2018, p. 366). Rosa distinguishes between flashes of resonance or resonant experience appearing here and there, on one hand, and a lasting basic capability for resonance and a lasting fundamental resonant trust on the other (p. 366). Such capability and trust, an attitude of fundamental trust, are necessary conditions and existential foundations for contingent and precarious resonances that cannot be controlled (p. 367).

Rosa develops this basic thesis in two directions. He first declares resonance to be a fundamental characteristic of humanity ${ }^{1}$. We humans are beings who have a fundamental capacity for resonance and a fundamental need for it. Both human subjectivity and social intersubjectivity are fundamentally shaped and built through the establishment of basic resonant relationships (Rosa 2016, p. 293). The longing for resonance is constitutive for man's humanity ${ }^{2}$. The concrete formation and development of the need for resonance, and thus the realization of a successful relationship with the world, depends on the specific historical, cultural, and social conditions in which people live (Laube 2018, p. 367). In this way, Rosa's theory reaches the level of social theory. Social conditions and factors cannot cause the onset of resonance-it is unavailable and cannot be controlled- however, they can affect person's sensibility or disposition for resonance, dispositional resonance, as Rosa expresses it; this is socially conditioned and therefore changeable (p. 368). This has already provided the basis for diagnostic and practical points about modernity. According to Rosa, modernity has two sides in terms of resonance. On the one hand, due to the growing fulfilment of the imperative of appropriating the world, it means a catastrophe of resonance (Rosa 2019c, p. 307ff), and on the other hand, greater sensitivity to resonance and, in many respects, specific resonance abilities have emerged in modernity (p. 357ff). According to Rosa, the escalation of the appropriation of the world in modernity has also produced an escalation of the longing for resonance. If modernity has brought a decline in the experience of resonance, Rosa, on the other hand, proves that the search for resonance 
has not ceased in it, but on the contrary: in alienated modernity, the longing for salvation has not dried up, but increased.

Sociology has the conceptual tools to expose it, revealing the alienating character of capitalist modernity. It can also outline a vision of a better world. However, it cannot produce a better world. It confines itself to helping to create social conditions that allow us to experience a vision of a better world and to preserve the memory of it. This is where Rosa's distinction between the structural sensibility for resonance conditioned by social conditions and individual contingent experiences of resonance comes into play. From the perspective of Rosa's theory, the task of sociology is to help regulate social conditions in such a way as to allow for contingent and individual resonance experiences. The better world that Rosa is talking about is not the better world itself, but a world that enables a vision of a better world and keeps it in our consciousness, in our memory. It is not a permanently resonant world, but a world that is possible in resonance, which is, at least in "this world", of a precarious nature (Laube 2018, pp. 368-9).

Rosa distinguishes three dimensions of resonance: horizontal (to people and communities) (Rosa 2019c, p. 202ff), diagonal (to inanimate things and artefacts) (p. 226ff), and vertical, to something that concerns and encompasses man as a whole (world, nature, history, God ... ) (p. 258ff). He distinguishes four main axes of vertical resonance: nature (p. 266ff), art (p. 280ff), religion, and history (p. 296ff). Let us now briefly outline the religious axis or religious experience as a resonance experience (Rosa 2019c, pp. 258-68; 2017, pp. 46-51).

\section{Religion within Rosa's Theory of Resonance}

For Rosa, religions are promises of resonance. "Something is present" is the basic form of our relationship to the world, Rosa notes, following Merleau-Ponty. The religious view, however, is that this is something fundamentally responsive, accommodating, and understanding. In theistic religions, this foundation is God. God is the foundation of the responsive world. In the light of Rosa's theory, religion is a relationship that promises a meaningful life in resonance and ensures that the fundamental dimension of the world is a relationship and not an alienation (Rosa 2019c, p. 258).

In this regard, Rosa specifically highlights Friedrich Schleiermacher and his relational view of religion (Schleiermacher 1996). Rosa emphasizes Schleiermacher's finding that an essential aspect of religious experience and the appeal of religion is in the idea of a responsive, accommodating world that touches us and that we are able to encounter. This view is, according to Rosa, compatible with the Western religious tradition, and, at the same time, most important to Rosa's own account of religion, as it is its essential and central part (Rosa 2019c, pp. 259-60).

In the twentieth century, a similar view was advocated by Martin Buber, for whom relationship is the first and fundamental aspect of all human existence. Buber was convinced that the longing for the I-Thou relationship is a fundamental and main human need (Buber 1995, pp. 26-28; Buber 2002, p. 31ff; Rosa 2019c, pp. 260-61). From the aspect of the thematization of religious aspects of resonance, I find it relevant to add at this point that it turns out that this longing is longing for God, or striving for him, because according to Buber, man longs for a lasting resonant relationship, not just a fragile, unstable one, such as the I-Thou relationship. Such a relationship, however, is possible only with God. The relationship with God is the foundation and source of every unstable self-relationship in the world or with the world, even if God himself is none of these relationships or a set of these relationships, because God is neither in the world nor the world. Moreover, according to Buber, with each I-Thou relationship, we enter more or less deeply into a relationship with God, or at least into his vestibule. The breath of the great Thou blows in every I-Thou relationship, as Buber wrote (Buber 1995, p. 7).

Rosa further develops his understanding of religion through the interpretation of prayer, worship, and religious rites (Rosa 2019c, pp. 261-62). The purpose of prayer is to achieve a deep resonance with the world as such, which can be seen from the fact that 
prayer is directed both inwardly and outwardly. A similar thing happens in meditative techniques. This view also explains why the translation of religion as a bond or connection is so suggestive, even though it may be etymologically questionable.

Rosa observes that in worship and religious rites such as the Eucharist and blessing, vertical resonance is associated with both a horizontal resonant axis between believers and diagonal resonant relationships, in terms of a resonant relationship to things like the cross, bread, chalice, and so on. The cross, chalice, holy water, etc. may suffice, at least for the Catholic believer, to make the vertical resonance sensually perceptible. In this perspective, Rosa notes that perhaps even the cross can be understood in terms of resonance theory as a connection between the horizontal and vertical dimensions of resonance. All dimensions of resonance (vertical, horizontal, and diagonal) are also present in the celebration of Christmas (Rosa 2019c, p. 263). Christmas is a family holiday (horizontal resonance), as well as a holiday of a special relationship to the crib (diagonal resonance) and to the child (vertical resonance) (Rosenstock 2018, pp. 406-7). Moreover, from the theological perspective, Christmas is evidence that in a relationship with man, God can also be transformed (Rosa 2019d, pp. 58-59), which is absolutely necessary in order to speak of the resonance between man and God. As Roland Rosenstock wrote

"With the birth of a child in a manger, God is transformed and-according to the experience of change into man-no longer remains the same. God puts himself in a relationship with himself and, by becoming a man, opens an accommodating resonant space for a relationship with man" (Rosenstock 2018, p. 406).

Rosa rejects the claim that his understanding that the essence of religion is the need to respond corresponds more to the Catholic view than to the Protestant view. He believes that this understanding is not only woven into Christianity, be it Catholic or Protestant, but also into Judaism and, in fact, into all other world religions, even if he does not undertake to prove the last thesis. Concerning Protestantism, his reflection on Protestant prayers and hymns, especially those written by Paul Gerhardt, is convincing. In connection with Gerhardt's hymns, as an evidence for his thesis, Rosa writes

"Protestantism shifts its sensitivity to resonance away from theology and into spheres of nature, in which the trace and voice of God are sought, and art or aesthetics, where they can be experienced in music and song" (Rosa 2019c, p. 264).

He connects the Protestant Paul Gerhardt with the Jew Martin Buber, whose I-Thou philosophy derives from his understanding of Hasidism (Buber 1955, p. xiii; Buber 2002, pp. 254-55; Schilpp and Friedman 1991, p. 33; Friedman 1981, pp. 111-12):

"Thus Martin Buber and Paul Gerhardt alike recognize as the essence of religion the existential human need for response along with the promise of this need's potential fulfillment" (Rosa 2019c, p. 264).

Christianity adds to this the understanding of God as a being of relationships. Important in this regard is the idea of perichoresis as well as the fact that in early Christianity God and the human soul were constitutively connected. At this point, Rosa affirms Peter Sloterdijk (Sloterdijk 2011, pp. 545-46), who explicitly defines the relationship between the soul and God as a fundamental and extremely "radical" (p. 546) resonance (Rosa 2019c, pp. 264-65).

The next religious term which Rosa interprets in the discourse of resonance theory is sin as alienation from God. This corresponds to the traditional Judeo-Christian understanding of sin as absence of relationship, especially in terms of the sin in the sense of superbia as a state where a person thinks that they are self-sufficient. From the point of view of resonant theory, $\sin$ is therefore a state of alienation in which the person is unwilling, not ready, or able to hear anyone other than themselves. Even for Martin Luther, this was the essence of sin. However, Luther and all monotheistic world religions are not primarily concerned with actually hearing some other voice, but about being open to resonance at all-that we want it, that we desire it, and that we aspire to obtain it. Religion is the 
promise that the world still hears us and sings or speaks to us, even if we do not hear it or we are unable to hear it, when all our axes of resonance are muted (Rosa 2019c, p. 265).

Doubts as to whether this sustaining and accommodating voice of the universe actually exists, or if it is just a comfortable illusion or self-deception, have been growing since the Enlightenment, as evidenced by critiques of religion from the 18th century onwards. In the end, the idea of a responsive world could not be preserved in the Enlightenment horizon, according to which the world is only something silent and guided by natural laws. If Pascal wrote in 1650, "The eternal silence of these infinite spaces frightens me" (Pascal 1910, p. 78, no. 206), but at the same time still believed and bet on God's voice for all this silence, Nietzsche, two centuries later, gave up all hope of ever hearing the beloved voice of the cosmos. He thought it was just a game of deception or delusion, as pleasant as it could be. One of the most radical views on the alienation of the world was taken by Albert Camus (Camus 1979) in the 20th century. His analysis led him to conclude that there can be no absurdity outside the human mind (p. 34). Nevertheless, an absurdity is neither only in man, nor only outside man, in the world, but depends on both, man and the world (pp. 26, 31-32, 34); moreover, absurdity is the only link between them (pp. 26, 34). He was convinced that this was the only honest position (p. 26) and that the deepest experience of the world was the experience of its complete alienation, the experience that the world could not be transformed to speak. This experience is a kind of epiphany that reveals the alienation, the silence of all things and the world (Rosa 2019c, p. 266). Camus was convinced that authentic life is only in accepting this truth and not in resorting to various self-deceptions: "Living is keeping the absurd alive. Keeping it alive is above all contemplating it (p. 53)". His understanding basically coincides with the position of the modern philosopher of nature Bernulf Kanitscheider, who said in a 2008 interview, "The universe says nothing to us" (Rosa 2019c, p. 267).

We see, therefore, that we can distinguish two basic views of the world in terms of resonance and alienation: on the one hand, the universe is silent and does not speak (to us), and on the other hand, the universe is resonant. However, we cannot decide between these two options with the help of logic and reason, but the decision depends on the individual's feeling, and this depends on their sensibility or disposition for resonance. As Rosa wrote

"Whether what lies at the 'bottom of the world' is the resonance of the universeas Schleiermacher, Buber, and James believe-or only the icy silence of bleak space—as Kanitscheider, Nietzsche, and Camus claim—cannot be determined by means of logic and reason. It can perhaps at most be 'felt,' and what comes of this test of feeling depends on a person's dispositional resonance or alienation as acquired not least through their educational experience (cf. Chapter VIII:3); in this context, alienation appears an unhappy concept, given its negative connotations" (p. 267).

According to Rosa, there is an anthropologically ingrained desire for resonance in man and a fear of the silence of the world. This fear can lead to collective religious violence (pp. 267-8), which seeks to ensure resonance with the world by force, which is not possible because resonance can neither be controlled nor forced, and because both sides must be active in resonance, to speak with their voice, which, however, is incompatible with coercion. Violent people mistake the subordination of people to their own will for the resonance of people with the world. Another way in which violence is linked to the fight against the world's silence is to try to awaken resonance through war or violence. This includes various accounts (neo-Nietzschean and others) in the 19th and 20th centuries that glorified war and other forms of violence (Nietzsche, Bataille, futurism, etc. (Taylor 2007, pp. 661-75)), but I think that this explanation can also be applied to many members of various extremist groups in the present who have joined such movements, for example, due to identity crisis, which can be interpreted as a crisis of resonance or the consequence of alienation. A person can be a citizen of a country, a member of a nation, an ethnic group, a family, in short, of something that (at least on the outside) determines their identity, but on the other hand, all their resonant channels are dead, silent, or blocked. Therefore, they 
try to revive them with radical gestures. Man tries in every way to break this alienation, as it is extremely difficult to bear. For example, Rosa defines depression as the death of human channels of resonance. Moreover, such a state of alienation signifies a crisis of meaning, meaninglessness, which can be interpreted as the absence of resonance ${ }^{3}$ (Mieth 2019, p. 185), as meaning is born when the wire of resonance begins to vibrate (Rosa 2019b, p. 199; Mieth 2019, p. 186).

Despite all the problems with resonance in modernity, human desire and longing for resonance have not dried up. However, more and more people have begun to look for vertical resonance along other axes than the religious axis. The most important are the following three: nature, history, and art. Modernity has found three other institutionalized ways to satisfy the desire for vertical resonance that are functionally equivalent to religion but do not require a metaphysical system of faith (Rosa 2019c, p. 268). Religion is thus in modernity only one of the axes of vertical resonance.

Vertical resonance is resonance with transcendence. The experience of transcendence awakens in people an existential hope. Therefore, they tend to experience transcendence in order to draw existential hope-which is the hope that the world and their life have meaning-from it. Vertical resonances are sources of human existential hope and therefore meaning. Resonance as such is therefore not identical with the experience of meaning but is its source. We can also say that the experience of meaning is grounded in it. People of modernity seek existential hope not only in religion but also in art, nature, and history. Religion is only one source of existential hope in modernity.

\section{The Significance of Rosa's Theory of Resonance for Religion and the Science of Religion}

Having thus briefly outlined Rosa's understanding of religion in terms of resonance theory, let us now take a closer look at the significance of Rosa's theory from the point of view of religion and the science of religion.

Due to the presentation of important religious topics in sociological form, Rosa's theory has received considerable attention in theology (Laube 2018, p. 363). However, the most important achievement of this theory for religion is the rehabilitation of the value of religion as an anthropological constant (Laube 2018, p. 370). This rehabilitation is based on the hypothesis of man's fundamental need for resonance, which is constitutive of man as man, of their humanity (ibid.). In the following, I will explain this claim and, at the same time, develop some other relevant claims about the significance of Rosa's resonance theory for religion and theology.

If we apply Rosa's findings to religion, we come to the following conclusions. The first consequence is the rehabilitation of that theology based on the proposition of the anthropologically based religiosity of man. Another consequence derived from Rosa's theory of resonance is that religion is a resonant relationship with the world that allows a person to feel supported and safe in the world. Such well-being is a good basis and a positive factor for a person's fundamental trust "in the world" and thus for the hope that (in the end) everything will be fine. A theology based on the liberal assumption of anthropologically rooted human religiosity (Schleiermacher) became in the past increasingly questionable. Rosa's modified version of the anthropological foundation of religion, based on human need for resonance, which includes the need for vertical resonance, has rehabilitated this theology, and it has gained weight again. Of course, resonance and religion do not coincide completely. There are other forms of resonance than religious ones. However, Rosa's notion of resonance is certainly deeply religiously impregnated (Laube 2018, p. 369). In addition, Rosa defines religion as a promise of resonance (Rosa 2016, p. 438). Thus, religion, if understood through the lens of Rosa's theory of resonance, is a resonant attitude toward the world that allows an individual to feel supported and even safe in the world that responds and accommodates them (Rosa 2016, p. 59). The third finding is that Rosa's sociology proves the indispensability of religion and piety in the modern world and places itself in the service of creating conditions in which man can 
actually shape and develop their need for resonance, and therefore their need for religion. By criticizing social conditions from the point of view of resonance, sociology puts itself at the service of the task of establishing such social conditions that enable man to shape and develop their need for resonance. Laube formulates it as follows:

"If sociology once emerged from the legacy of an enlightened critique of religion, now with Rosa it takes on not only the task of proving the indispensability of religion and piety in modernity, but also creating an appropriate social framework for their success. Theology really can't want more from sociology" (Laube 2018, p. 370).

\section{Conclusions}

In the article, I dealt with Rosa' resonance theory. As a part of the consideration of it from the sociological point of view, I emphasized the distinction between a contingent resonance experience and a permanent dispositional resonance. The first is unavailable and cannot be controlled, while the formation and development of the second depends on concrete social and cultural conditions and factors to the formation of which sociology can contribute. Since religion is an important factor of resonance, sociology-within the framework of Rosa's theory-thus enters the service of religion. The main significance of resonance theory for religion and the science of religion is in the rehabilitation of religion as an anthropological constant. It follows that Rosa's theory of resonance is an important contribution to substantiating the importance of religion and supporting its cultivation. Since we start from the assumption that religion is a key positive factor in the development of hope, we find that Rosa's theory is an important contribution and support to the flourishing of hope due to its scientific support for religion. Another contribution of Rosa's theory to hope is that it helps us understand the connection between resonance and existential hope and meaning, and thus contributes to our being more successful in developing existential hope and discovering and experiencing the meaning of our lives and world. This is important for our quality of life.

Funding: The Research Programme Ethical-religious Grounds and Perspectives of the Society and the Religious Studies in Context of Education and Violence (P6-0269) and the basic research projects Holistic approach to business and human rights: a normative reform of Slovenian and international legal order (J5-1790), and Interreligious Dialogue-a Basis for Coexisting Diversity in the Light of Migration and the Refugee Crisis (J6-9393) are financed by the Slovenian Research Agency. This article was published with the support of the mentioned programme and projects. I thank the agency for the support.

Institutional Review Board Statement: Not applicable.

Informed Consent Statement: Not applicable.

Data Availability Statement: Not applicable.

Conflicts of Interest: The authors declare no conflict of interest.

\section{Notes}

1 Laube points to Rosa's inconsistency: Rosa says he makes no substantial claims about human nature. However, when Rosa argues that the ability to satisfy the anthropological need for resonance depends on the possibility of stable resonant axes, then there is a related item about the essence of human nature (Laube 2018, p. 367, n. 13).

2 Rosa, with his thesis on the anthropological need for resonance, seems to inherit the hermeneutic thesis on man's anthropological need for meaning, even though Rosa himself is very reserved about the discourse of meaning (Rosa 2016, p. 303ff). Laube explains this restraint by saying that the notion of meaning cannot capture the moment of transformation that is so important for Rosa's notion of resonance (Laube 2018, p. 367, n. 14).

3 At this point, Rosa agrees with Camus.

\section{References}

Buber, Martin. 1955. The Legend of the Baal-Shem. London: Horovitz Publishing. 
Buber, Martin. 1995. Ich und Du. Stuttgart: Reclam.

Buber, Martin. 2002. Between Man and Man. London: Routledge \& Kegan Paul.

Camus, Albert. 1979. The Myth of Sisyphus. Harmondswort: Penguin Books.

Friedman, Maurice. 1981. Martin Buber's Life and Work. The Early Years 1878-1923. New York: E. P. Dutton.

Hübner, Jörg. 2021. Reich-Gottes-Hoffnung als Auferstehung-Resonanz. Hartmut Rosas Resonanzkonzept ins Gespräch gebracht: Ein theologisches Experiment. Evangelische Theologie 81: 223-36. [CrossRef]

Kläden, Tobias, and Michael Schüßler, eds. 2017. Zu Schnell Für GOTT? Theologische Kontroversen zu Beschleunigung und Resonanz. Freiburg: Herder.

Klun, Branko. 2020. Rezilienca in resonanca: V iskanju nove drže do sveta. Bogoslowni Vestnik 80: 281-92. [CrossRef]

Laube, Martin. 2018. Eine bessere Welt ist möglich. Theologische Überlegungen zur Resonanztheorie Hartmut Rosas. Pastoraltheologie 107: 356-70. [CrossRef]

Mieth, Dietmar. 2019. Dynamische Stabilisierung und resonante Weltbeziehung. In Resonanz. Im interdisziplinären Gespräch mit Hartmut Rosa. Edited by Jean-Pierre Wils. Baden-Baden: Nomos, pp. 179-87.

Pascal, Blaise. 1910. Thoughts. Letters. Minor Works. New York: P. F. Collier \& Son Corporation.

Peters, Christian Helge, and Peter Schulz, eds. 2017. Resonanzen und Dissonanzen. Hartmut Rosas Kritische Theorie in der Diskussion. Bielefeld: Transcript Verlag.

Rosa, Hartmut. 2016. Resonanz. Eine Soziologie der Weltbeziehung. Berlin: Suhrkamp.

Rosa, Hartmut. 2017. Gelingendes Leben in der Beschleunigungsgesellschaft. Resonante Weltbeziehungen als Schlüssel zur Überwindung der Eskalationsdynamik der Moderne. In Zu Schnell Für Gott? Theologische Kontroversen zu Beschleunigung und Resonanz. Edited by Tobias Kläden and Michael Schüßler. Freiburg, Basel and Wien: Herder, pp. 18-51.

Rosa, Hartmut. 2018. Unverfügbarkeit. Wien: Residenz Verlag.

Rosa, Hartmut. 2019a. Resonanz als Schlüsselbegriff der Sozialtheorie. In Resonanz. Im Interdisziplinären Gespräch mit Hartmut Rosa. Edited by Jean-Pierre Wils. Baden-Baden: Nomos, pp. 11-30.

Rosa, Hartmut. 2019b. Zur Kritik und Weiterentwicklung des Resonanzkonzepts. In Resonanz. Im Interdisziplinären Gespräch Mit Hartmut Rosa. Edited by Jean-Pierre Wils. Baden-Baden: Nomos, pp. 191-212.

Rosa, Hartmut. 2019c. Resonance: A Sociology of Our Relationship to the World. Cambridge and Medford: Polity Press.

Rosa, Hartmut. 2019d. The Uncontrollability of the World. Cambridge and Medford: Polity Press.

Rosa, Hartmut, and Christoph Henning, eds. 2019. The Good Life Beyond Growth: New Perspectives. New York: Routledge.

Rosenstock, Roland. 2018. Etwas, was nicht ist und doch nicht nur nicht ist. Konturen einer resonanzsensiblen Theologie im Gespräch mit Hartmut Rosa. Pastoraltheologie 107: 401-7. [CrossRef]

Schilpp, Paul Arthur, and Maurice Friedman, eds. 1991. The Philosophy of Martin Buber. La Salle: Open Court.

Schleiermacher, Friedrich. 1996. On Religion: Speeches to Its Cultured Despisers. Cambridge: Cambridge University Press.

Sloterdijk, Peter. 2011. Bubbles: Spheres I. Los Angeles: Semiotext(e).

Taylor, Charles. 2007. A Secular Age. Cambridge and London: The Belknap Press of Harvard University Press.

Wils, Jean-Pierre, ed. 2019. Resonanz. Im Interdisziplinären Gespräch Mit Hartmut Rosa. Baden-Baden: Nomos.

Žalec, Bojan. 2021. Resonance as integral part of human resilience. XLinguae 14: 139-149. [CrossRef] 